Volume 2 Nomor 2, Desember 2019

E-ISSN : 2655-7347

\title{
TANGGUNG JAWAB PENGEMBANG (DEVELOPER) DALAM PENJUALAN SATUAN UNIT APARTEMEN TERKAIT KETIADAAN IZIN MENDIRIKAN BANGUNAN (STUDI KASUS APARTEMEN 45 ANTASARI JAKARTA SELATAN)
}

\author{
Riza Mediana Fitri \\ (Mahasiswi Program S1 Fakultas Hukum Universitas Tarumanagara)
}

(E-mail: medianariza@gmail.com)

\section{Dr. Gunawan Djajaputra S.H., M.H \\ (Corresponding Author)}

(Dosen Hukum Real Estate dan Perizinan Fakultas Hukum Universitas Tarumanagara, Meraih Sarjana Hukum dari Universitas Indonesia, Magister Hukum dari Universitas Indonesia, Doktor Hukum dari

Universitas Indonesia)

\begin{abstract}
In the sale of apartment, developer can carry out marketing before the construction are done or commonly called Pre Project Selling system, the selling and buying must be written in the form of Sales and Purchase Agreement. To do sales by pre project selling, developer must to fulfill administrative requirements, one of which is Building Permits. Moreover, because the selling and buying must be written in the form of Sales and Purchase Agreement, one of requirements to get Sales and Purchase Agreement is to have building permits. In the construction of apartment developers also must have building permits of apartment which is given from regional government. But in reality, there are still project of apartement construction doesn't have building permits, for example 45 Antasari Apartment. Building permits are necessary to ensure legal certainty of a building. Therefore, responsibility of developer is necessary if he neglect one's duties. By analysis the author suggest the responsibilities of developer can be interpreted more, which will be further analysis using the normative legal research by examining primary and secondary legal materials that have been collected and processed for the formulation of research conclusions.
\end{abstract}

Keywords : Responsibilities Of Developers, Pre Project Selling, Building Permits.

\section{Pendahuluan}

\section{A. Latar Belakang}

Tempat tinggal merupakan suatu kebutuhan yang penting bagi setiap orang dan juga dijamin dalam Undang-Undang Dasar Negara Republik Indonesia Tahun 1945 di mana setiap orang berhak untuk hidup sejahtera lahir dan batin bertempat tinggal serta mendapatkan lingkungan hidup yang baik dan sehat sebagaimana yang 
Volume 2 Nomor 2, Desember 2019

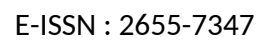

diamanatkan dalam Pasal 28 UUD NRI 1945. Dengan adanya pertumbuhan penduduk yang begitu pesat mengakibatkan peningkatan akan suatu tempat tinggal, namun pertumbuhan penduduk tersebut tidak sebanding dengan luas lahan yang ada. Oleh karena itu, pembangunan perumahan dan permukiman di daerah perkotaan dan daerah yang memiliki penduduk yang cukup padat mulai mengacu kepada pembangunan perumahan dengan struktur vertikal yang dikenal dengan sebutan apartemen atau rumah susun. ${ }^{1)}$

Diketahui bahwa konsep pembangunan rumah susun atau apartemen ini ada untuk memberikan jawaban atas keterbatasan luasan lahan yang tersedia yang tidak sebanding dengan jumlah penduduk yang ada, hal tersebut menyebabkan kurang memungkinkan untuk melakukan pembangunan perumahan dengan struktur horizontal. Berdasarkan hal tersebutlah pemerintah mengeluarkan peraturan perundang-undangan tentang Rumah Susun yakni Undang-Undang Nomor 20 Tahun 2011 tentang Rumah Susun, melalui Undang-Undang tersebut telah diatur ketentuan dan kebijakan mengenai rumah susun di Indonesia. ${ }^{2)}$

Setiap orang dan atau pemerintah yang melakukan pembangunan rumah susun atau apartemen disebut dengan pelaku pembangunan rumah susun/pengembang/developer. Dalam melakukan pembangunan, pemasaran dan penjualan rumah susun pengembang harus memenuhi syarat-syarat yang diatur dalam Undang-Undang Nomor 20 Tahun 2011 tentang Rumah Susun. Misalnya apabila pemasaran apartemen dilakukan sebelum pembangunan selesai, maka pengembang harus memenuhi persyaratan-persyaratan seperti kepastian peruntukan ruang, kepastian hak atas tanah, kepastian status penguasaan rumah susun,perizinan

1) Amarendra S.Aminah dan R. Suharto, "Tinjauan Yuridis Terhadap Pembangunan Apartemen Utara Yogyakarta Ditinjau Dari Undang-Undang Nomor 32 Tahun 2009 Tentang Perlindungan Dan Pengelolaan Lingkungan Hidup”, Diponegoro Law Review, Volume 5 Nomor 2 Tahun 2016, hal. 2.

2) M.Ridwan, "Analisis Yuridis Kekuatan Hukum Atas Sertipikat Satuan Rumah Susun Hunian Atau Campuran Pasca Terbitnya Undang-Undang Nomor 20 tahun 2011 tentang Rumah Susun”, Premise law Jural, Volume 8 Tahun 2017, hal. 2. 


\section{Jurnal Hukzum Adigamâ}

Riza Mediana Fitri \& Gunawan Djajaputra

TANGGUNG JAWAB PENGEMBANG (DEVELOPER) DALAM PENJUALAN SATUAN UNIT APARTEMEN TERKAIT KETIADAAN IZIN MENDIRIKAN BANGUNAN (STUDI KASUS APARTEMEN 45 ANTASARI JAKARTA SELATAN)

Volume 2 Nomor 2, Desember 2019

E-ISSN : 2655-7347

pembangunan rumah susun; serta jaminan atas pembangunan rumah susun dari lembaga penjamin. ${ }^{3)}$

Dalam hal pemasaran dilakukan sebelum pembangunan rumah susun atau apartemen selesai, maka segala sesuatu yang dijanjikan oleh pihak pengembang berlaku sebagai Perjanjian Pengikatan Jual Beli (PPJB). PPJB tersebut dapat dilakukan apabila pengembang telah memenuhi persyaratan seperti: status kepemilikan tanah, kepemilikan IMB, ketersediaan prasarana, sarana, dan utilitas umum, keterbangunan paling sedikit 20\% (dua puluh persen); dan hal yang diperjanjikan. ${ }^{4)}$

Sedangkan proses jual beli yang dilakukan sesudah pembangunan apartemen selesai, maka dilakukan melalui akta jual beli (AJB). Suatu pembangunan apartemen dikatakan telah selesai apabila telah diterbitkannya: Sertifikat Laik Fungsi; dan Sertifikat Hak Milik Satuan Rumah Susun atau Surat Kepemilikan Bangunan Gedung.

Pembangunan rumah susun komersial dalam bentuk apartemen memang sedang mengalami peningkatan yang pesat serta persaingan yang cukup ketat untuk menarik minat konsumen. Hal tersebut terjadi dikarenakan rumah susun atau apartemen menjadi suatu alternatif pemecah masalah dalam hal kebutuhan akan tempat tinggal untuk di terapkan di kota-kota besar yang memiliki penduduk padat serta lahan yang terbatas. ${ }^{6)}$ Berdasarkan hal tersebut timbullah suatu cara untuk menjual properti seperti perumahan dan apartemen dengan cepat dan praktis yang dilakukan oleh pengembang yang dikenal dengan sistem Pre Project Selling.

Jika kita mengacu pada Undang-Undang Nomor 20 Tahun 2011 tentang Rumah Susun, khususnya dalam Pasal 42 Ayat (1) Undang-Undang Nomor 20 Tahun

3) Indonesia, Undang-Undang Nomor 20 Tahun 2011 tentang Rumah Susun (Lembaran Negara Republik Indonesia Tahun 2011 Nomor 108, Tambahan Lembaran Negara Republik Indonesia Nomor 5252), Pasal 42 Ayat (2).

4) Ibid, Pasal 43.

5) Ibid, Pasal 44.

6) Lintang Yudhantaka, "Keabsahan Kontrak Jual Beli Rumah Susun dengan Sistem Pre Project Selling”, Jurnal Yuridika, Volume 32 No.1 Januari 2017, hal. 84. 
Volume 2 Nomor 2, Desember 2019

E-ISSN : 2655-7347

2011 tentang Rumah Susun, yang pada intinya mengamanatkan bahwa pengembang dapat melakukan pemasaran apartemen sebelum pembangunannya selesai dilaksanakan, maka sistem penjualan apartemen secara Pre Project Selling memang tidak dilarang. Sistem Pre Project Selling ini dilakukan oleh pengembang dengan menjual atau memasarkan apartemen kepada pembeli dengan membuat suatu PPJB sebelum objek jual beli tersebut dibangun, dan pembeli akan membayar sejumlah uang awal atau biasa disebut booking fee yang selanjutnya diikuti dengan pembayaran angsuran/cicilan apartemen.

Dalam melakukan penjualan secara Pre Project Selling ini pengembang harus memenuhi syarat yang diatur dalam Undang-Undang Nomor 20 Tahun 2011 tentang Rumah Susun, misalnya dalam melakukan pembangunan suatu apartemen, pengembang wajib memenuhi persyaratan administratif yang berupa status hak atas tanah dan Izin Mendirikan Bangunan sebagaimana yang diamanatkan dalam Pasal 28 Undang-Undang Nomor 20 Tahun 2011 tentang Rumah Susun. ${ }^{7}$ Kemudian selanjutnya di dalam Pasal 42 Ayat (2) pun menyebutkan apabila pemasaran dilakukan sebelum pembangunan, maka pengembang harus mempunyai perizinan pembangunan rumah susun yang ditunjukkan melalui Izin Mendirikan Bangunan.

Selain itu pengaturan persayaratan untuk memiliki IMB pun juga diatur dalam Undang-Undang Nomor 28 Tahun 2002 tentang Bangunan Gedung, yang dimaksud dengan bangunan gedung adalah wujud fisik hasil pekerjaan konstruksi yang menyatu dengan tempat kedudukannya, sebagian atau seluruhnya berada di atas dan/atau di dalam tanah dan/atau air, yang berfungsi sebagai tempat manusia melakukan kegiatannya, baik untuk hunian atau tempat tinggal, kegiatan keagamaan, kegiatan usaha, kegiatan sosial, budaya, maupun kegiatan khusus.Bangunan gedung diselenggarakan berlandaskan asas kemanfaatan, keselamatan, keseimbangan, dan harmonisasi dengan lingkungannya. Rumah susun sendiri sangat erat kaitannya

7) Indonesia, Undang-Undang Nomor 20 Tahun 2011 tentang Rumah Susun (Lembaran Negara Republik Indonesia Tahun 2011 Nomor 108, Tambahan Lembaran Negara Republik Indonesia Nomor 5252), Pasal 28. 
Volume 2 Nomor 2, Desember 2019

E-ISSN : 2655-7347

dengan bangunan gedung, diketahui bahwa rumah susun termasuk klasifikasi daripada bangunan gedung untuk fungsi hunian, di mana dalam Undang-Undang Nomor 28 Tahun 2002 tentang Bangunan Gedung pun diatur persyaratan-persyaratan bangunan gedung seperti persyaratan teknis dan persyaratan administratif sesuai dengan fungsi bangunan gedung.

Diketahui bahwa persyaratan teknis bangunan gedung tersebut meliputi persyaratan tata bangunan dan persyaratan keandalan bangunan gedung. Sedangkan persyaratan administratif bangunan gedung meliputi persyaratan status hak atas tanah, status kepemilikan bangunan gedung, dan izin mendirikan bangunan. Izin Mendirikan Bangunan sendiri merupakan bagian dari persyaratan administratif yang diatur dalam Undang-Undang Nomor 28 Tahun 2002 tentang Bangunan Gedung.

Izin Mendirikan Bangunan merupakan suatu izin yang akan diberikan oleh pemerintah daerah setempat untuk melakukan kegiatan pembangunan. Sebagai pihak yang bertanggung jawab dalam hal melakukan pembangunan, pemasaran dan penjualan apartemen, pengembang wajib memperoleh izin dari pemerintah setempat. Selain itu Izin Mendirikan Bangunan sendiri memiliki manfaat dan kegunaan baik bagi pengembang ataupun pembeli apartemen yakni untuk mewujudkan suatu bangunan gedung yang memenuhi segala persyaratan baik administratif maupun teknis sesuai dengan fungsi dan peruntukkannya agar terciptanya suatu bangunan gedung yang tertib yang sesuai dengan rencana tata kota, menjamin kepastian hukum suatu bangunan gedung agar memberikan perlindungan hukum baik bagi pengembang maupun pembeli serta menjamin keandalan bangunan gedung untuk memberikan keamanan dan kenyamanan baik bagi pihak pengembang maupun pembeli. ${ }^{8)}$

Namun pada kenyataannya meskipun sudah diatur sedemikian rupa hal yang berkaitan dengan apartemen atau rumah susun seperti syarat-syarat yang harus

\footnotetext{
${ }^{8)}$ Indonesia, Peraturan Menteri Pekerjaan Umum dan Perumahan Rakyat Republik Indonesia Nomor 05/PRT/M/2016 tentang Izin Mendirikan Bangunan Gedung, Berita Negara Republik Indonesia Tahun 2016 Nomor 276, Pasal 2.
} 
Volume 2 Nomor 2, Desember 2019

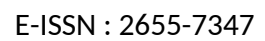

dipenuhi oleh pengembang dalam melakukan penjualan apartemen secara Pre Project Selling, dalam prakteknya masih terdapat apartemen di Jakarta yang belum memenuhi persyaratan yang diatur dalam Undang-Undang Nomor 20 Tahun 2011 tentang Rumah Susun, misalnya pada apartemen 45 Antasari yang pembangunannya dilakukan oleh PT. Prospek Duta Sukses. Di mana penjualan apartemen secara Pre Project Selling yang dilaksanakan oleh PT. Prospek Duta Sukses melanggar ketentuan yang tercantum dalam Undang-Undang Nomor 20 Tahun 2011 tentang Rumah Susun yakni tidak adanya Izin Mendirikan Bangunan. Hal tersebut berawal ketika pihak pengembang melakukan pemasaran apartemen 45 Antasari dengan menawarkan janji bahwa penyerahan unit apartemen dilaksanakan pada Oktober 2017 serta dalam melakukan pembangunan apartemen 45 Antasari, pengembang telah memiliki perizinan-perizinan yang lengkap untuk melakukan pembangunan. Sehingga para pembeli tertarik untuk membeli unit apartemen tersebut dan telah melakukan pembayaran booking fee dan pembayaran DP.

Dan diketahui ternyata pembangunan apartemen 45 Antasari terhenti tanpa adanya alasan yang jelas dari pihak pengembang kemudian berdasarkan surat Dinas Penataan Kota Provinsi DKI Jakarta menyebutkan bahwa Izin Mendirikan Bangunan apartemen 45 Antasari belum diterbitkan. Berdasarkan hal tersebut tanggung jawab dari pihak pengembang menjadi sangat penting dan sangat dibutuhkan apabila pengembang tidak menjalankan kewajibannya tersebut.

Berdasarkan hal tersebutlah, penulis ingin menganalisis lebih jauh mengenai tanggung jawab pengembang yang melakukan penjualan satuan unit apartemen 45 Antasari yang belum memiliki Izin Mendirikan Bangunan serta hal-hal apa saja yang menyebabkan pengembang dapat melakukan penjualan satuan unit apartemen sebelum adanya Izin Mendirikan Bangunan, karena tidak selarasnya norma aturan dalam Undang-Undang Nomor 20 Tahun 2011 tentang Rumah Susun dengan praktek pemasaran dan penjualan apartemen. Oleh sebab itu penulis mengambil judul mengenai “TANGgUNG JAWAB PENGEMBANG (DEVELOPER) DALAM 
Volume 2 Nomor 2, Desember 2019

E-ISSN : 2655-7347

\section{PENJUALAN SATUAN UNIT APARTEMEN TERKAIT KETIADAAN IZIN MENDIRIKAN BANGUNAN (IMB) (STUDI KASUS APARTEMEN 45 ANTASARI JAKARTA SELATAN)”.}

\section{B. Rumusan Masalah}

Berdasarkan latar belakang yang telah dijelaskan, maka dirumuskan suatu permasalahan ke dalam suatu pertanyaan, yakni bagaimanakah tanggung jawab pengembang dalam melakukan penjualan satuan unit apartemen terkait ketiadaan Izin Mendirikan Bangunan serta hal-hal apa saja yang menyebabkan pengembang dapat melakukan penjualan satuan unit apartemen sebelum memiliki Izin Mendirikan Bangunan?

\section{Pembahasan}

PT. Prospek Duta Sukses selaku pengembang yang melakukan pembangunan, pemasaran dan penjualan satuan unit apartemen 45 Antasari memiliki kewajiban untuk memenuhi segala persyaratan yang diatur dalam Undang-Undang Nomor 20 Tahun 2011 tentang Rumah Susun, khususnya kewajiban untuk memenuhi segala persyaratan administratif dalam melakukan pembangunan apartemen yakni mengenai kepastian status hak atas tanah serta Izin Mendirikan Bangunan sebagaimana yang diamanatkan dalam Pasal 28.

Selain itu, karena penjualan apartemen 45 Antasari dilaksanakan secara Pre Project Selling, maka pengembang pun juga harus memenuhi persyaratan yang diatur dalam Pasal 42 Ayat 2 Undang-Undang Nomor 20 Tahun 2011 tentang Rumah Susun yang mengamanatkan bahwa pengembang memang dimungkinkan untuk melakukan pemasaran rumah susun sebelum pembangunan rumah susun selesai dilaksanakan, namun hal tersebut dapat dilakukan pengembang setelah memenuhi persyaratan yang tercantum dalam Pasal 42 Ayat 2 tersebut, di mana salah satu syarat nya adalah adanya perizinan pembangunan rumah susun yang ditunjukkan dengan IMB.

Ketika pengembang melakukan pemasaran serta penjualan apartemen yang tidak memiliki IMB kepada calon pembeli / konsumen, hal tersebut menunjukkan 
Volume 2 Nomor 2, Desember 2019

E-ISSN : 2655-7347

bahwa pengembang tidak memiliki itikad baik sejak semula, karena memiliki IMB merupakan suatu hal yang wajib dimiliki pengembang sebelum melakukan pembangunan, pemasaran dan penjualan apartemen. Tentu saja jika pengembang belum memiliki IMB, maka pengembang tidak boleh melakukan pembangunan serta penjualan apartemen, yang mana seharusnya kewajiban untuk mengurus segala perizinan pembangunan apartemen seperti IMB tersebut sudah harus dipenuhi pengembang sejak awal sebelum melakukan pembangunan apartemen dan pengembang pun sudah pasti mengetahui akan segala hal yang wajib dipenuhinya sebagai penjual dalam melakukan pembangunan, pemasaran dan penjualan apartemen karena telah diatur sedemikian rupa dalam Pasal 28 dan Pasal 42 Ayat 2 UndangUndang Nomor 20 Tahun 2011 tentang Rumah Susun. Apabila pengembang tidak melaksanakan kewajibannya, maka pengembang dapat dibebankan tanggung jawab atas perbuatannya tersebut.

Tanggung jawab sendiri memiliki pengertian bahwa adanya suatu kewajiban untuk menanggung segala sesuatu yang apabila terjadi apa-apa atau terjadi sesuatu boleh dituntut, dipersalahkan ataupun diperkarakan (Menurut Kamus Besar Bahasa Indonesia (KBBI). Sedangkan menurut kamus hukum, tanggung jawab adalah suatu keseharusan bagi seseorang untuk melaksanakan apa yang telah diwajibkan kepadanya. ${ }^{9}$ Pada umumnya, prinsip tanggung jawab dalam hukum terdiri dari: ${ }^{10)}$

1) Tanggung jawab berdasarkan kesalahan (liability based on fault);

Berdasarakan prinsip tanggung jawab ini Unsur kesalahan yang dilakukan oleh seseorang merupakan suatu hal yang mewajibkan seseorang dapat dimintakan pertanggungjawabannya secara hukum. Hal tersebut erat kaitannya dengan Pasal 1365 KUHPerdata yang mengatur mengenai perbuatan melawan hukum, di mana menurut Pasal 1365 KUHPerdata mewajibkan terpenuhinya unsur-unsur sebagai berikut:

\footnotetext{
9) Andi Hamzah, Kamus Hukum, (Ghalia Indonesia, 2005).

10) Celina Tri Siwi Kristiyanti, Hukum Perlindungan Konsumen, (Jakarta: Sinar Grafika, 2009), hal. 92.
} 
Volume 2 Nomor 2, Desember 2019

E-ISSN : 2655-7347

a. Adanya perbuatan yang melawan hukum;

b. Adanya unsur kesalahan;

c. Adanya kerugian yang diderita; dan

d. Adanya hubungan kausalitas antara perbuatan dan kerugian.

2. Praduga selalu bertanggung jawab (presumption of liability);

Menurut prinsip ini beban pembuktian berada pada pihak tergugat di mana tergugat akan selalu dianggap bertanggung jawab sampai ia dapat membuktikan bahwa kesalahan tersebut bukan disebabkan oleh dirinya atau memang ia tidak bersalah.

3. Praduga selalu tidak bertanggung jawab (presumption of non liability);

Menurut prinsip ini tergugat selalu dianggap tidak bertanggung jawab sampai dapat dibuktikan bahwa benar ia melakukan kesalahan atau kerugian yang terjadi itu disebabkan oleh dirinya, yang mana prinsip ini merupakan kebalikan dari prinsip praduga untuk selalu bertanggung jawab.

4. Tanggung jawab mutlak (strict liability);

Menurut prinsip ini pelaku wajib bertanggungjawab secara mutlah terhadap hal-hal yang telah menyebabkan kerugian bagi pihak lain dan tidak ada keharusan untuk membuktikan terdapatnya unsur-unsur kesalahan dari pelaku tersebut.

5. Tanggung jawab dengan pembatasan (limitation of liability).

Biasanya prinsip ini dicantumkan sebagai klausula eksonerasi yang dibuat oleh pelaku usaha dalam perjanjian standar yang telah dibuatnya.

Jika mengacu pada teori tanggung jawab yang telah diuraikan di atas, maka menurut penulis tanggung jawab atas dasar unsur kesalahan memiliki korelasi yang cukup kuat terhadap isu hukum yang sedang diangkat, di mana tanggung jawab berdasarkan kesalahan erat kaitannnya dengan Pasal 1365 KUHPerdata yang mengatur mengenai perbuatan melawan hukum, yang mana unsur-unsur perbuatan 
Volume 2 Nomor 2, Desember 2019

E-ISSN : 2655-7347

melawan hukum yang dilakukan oleh pihak pengembang dapat penulis uraikan sebagai berikut: ${ }^{11}$

1) Adanya suatu perbuatan

Diketahui bahwa pengembang dalam hal ini PT. Prospek Duta Sukses melakukan suatu perbuatan yakni melakukan pembangunan, pemasaran dan penjualan satuan unit apartemen 45 Antasari dengan memberikan informasi bahwa serah terima unit apartemen akan dilaksanakan pada Oktober 2017 serta telah dilengkapinya segala perizinan untuk melaksanakan pembangunan apartemen 45 Antasari.

2) Perbuatan tersebut melawan hukum

Jika melihat kasus pembangunan apartemen 45 Antasari, PT. Prospek Duta Sukses sebagai pengembang tentu mengetahui akan segala persyaratan dan perizinanyang harus dipenuhinya sebelum melakukan pembangunan, pemasaran dan penjualan apartemen, namun pada kenyataanya pihak pengembang tidak memenuhi salah satu persyaratan dan perizinan tersebut khususnya mengenai ketiadaan Izin Mendirikan Bangunan dan tetap melakukan pemasaran dan pembangunan apartemen serta tidak memberi informasi yang jelas mengenai terhentinya pembangunan apartemen 45 Antasari.

Diketahui bahwa suatu perbuatan dapat dikatakan sebagai perbuatan yang melawan hukum, apabila mencakup hal-hal sebagaimana dibawah ini yakni:

a. Perbuatan tersebut melanggar Undang-Undang yang berlaku

Dalam kasus pembangunan apartemen 45 Antasari, pihak pengembang dalam hal ini PT. Prospek Duta Sukses melanggar kententuan yang tercantum dalam UndangUndang Nomor 20 Tahun 2011 tentang Rumah Susun, yakni Pasal 28 UndangUndang Nomor 20 Tahun 2011 yang mewajibkan PT. Prospek Duta Sukses untuk memenuhi kententuan/persyaratan administratif dalam melakukan pembangunan

11) Munir Fuady, Perbuatan Melawan Hukum, Cetakan ke-4 (Bandung: PT Citra Aditya Bakti), hal. 10. 
Volume 2 Nomor 2, Desember 2019

E-ISSN : 2655-7347

rumah susun dalam hal ini apartemen, yakni berupa: Status hak atas tanah dan Izin Mendirikan Bangunan serta karena pemasaran apartemen menggunakan sistem Pre Project Selling, maka PT. Prospek Duta Sukses juga wajib memenuhi ketentuan yang tercantum dalam Pasal 42 Ayat 2 di mana salah satu syarat yang diatur dalam Pasal tersebut adalah perizinan pembangunan rumah susun yang ditunjukkan dengan Izin Mendirikan Bangunan.

Dikarenakan PT. Prospek Duta Sukses belum memiliki Izin Mendirikan Bangunan, maka PPJB pun tidak mungkin terlaksana karena salah satu syarat PPJB menurut Pasal 43 Ayat (2) huruf b adalah kepemilikan Izin Mendirikan Bangunan.

b. Melanggar hak subjektif orang lain

Diketahui bahwa hak pembeli selaku konsumen telah dilanggar oleh PT. Prospek Duta Sukses yakni hak pembeli atas informasi yang benar, jelas dan jujur mengenai jaminan barang dan atau jasa sebagaimana yang disebutkan dalam Pasal 4 Ayat (c) Undang-Undang Nomor 8 Tahun 1999 tentang Perlindungan Konsumen. Di mana dalam hal ini pihak pengembang tidak memberikan informasi yang benar, jelas dan jujur terkait perizinan pembangunan apartemen mengenai ketiadaan Izin Mendirikan Bangunan.

c. Bertentangan dengan kewajiban hukum si pelaku

Kewajiban hukum yang dilanggar oleh pihak pengembang yakni dilanggarnya persyaratan yang tercantum dalam Pasal 28 dan Pasal 42 Ayat 2 Undang-Undang Nomor 20 Tahun 2011 tentang Rumah Susun yang pada intinya mewajibkan pihak pengembang untuk memiliki Izin Mendirikan Bangunan pada saat melakukan pembangunan dan pemasaran apartemen dengan sistem Pre Project Selling.

d. Bertentangan dengan kesusilaan atau kepatutan

Suatu perbuatan yang dianggap bertentangan dengan kesusilaan dan kepatutan merupakan perluasan yang penting dari penafsiran suatu perbuatan melawan hukum, di mana suatu perbuatan yang bertentangan dengan kesusilaan dan kepatutan memang dapat berubah dari waktu ke waktu. Bahkan ada yang mengatakan bahwa suatu 
Volume 2 Nomor 2, Desember 2019

E-ISSN : 2655-7347

perbuatan yang bertentangan dengan kepatutan sudah pasti bertentangan dengan kesusilaan. Menurut Shidarta, suatu perbuatan yang dikenal sebagai "bertentangan dengan kepatutan” adalah jika: ${ }^{12)}$

(1) Perbuatan tersebut sangat merugikan orang lain tanpa kepentingan yang layak.

Di mana perbuatan pihak pengembang yang tidak memiliki IMB sangat merugikan pihak pembeli/konsumen karena setiap bangunan gedung dalam hal ini apartemen harus memiliki IMB untuk mewujudkan bangunan gedung sesuai dengan fungsi dan peruntukkannya serta menjamin keamanan bangunan gedung karena telah terpenuhinya syarat administratif maupun teknis bangunan gedung tersebut, juga untuk menjamin kepastian hukum dalam penyelenggaraan IMB, selain itu pembangunan yang tidak memiliki IMB dapat dikategorikan sebagai suatu bangunan illegal karena tidak adanya IMB yang mana dapat dikenakan sanksi administratif misalnya seperti sanksi penghentian sementara pembangunan tersebut sampai pada sanksi pembongkaran bangunan yang tentu saja hal tersebut menimbulkan kerugian kepada pembeli karena tidak bisa lagi menikmati manfaat dari apartemen tersebut.

(2) Perbuatan itu tidak berguna atau menimbulkan bahaya bagi orang lain.

Perbuatan dari pihak pengembang yang tidak memiliki IMB tentu saja tidak berguna karena perbuatan yang dilakukannya tersebut melanggar ketentuan peraturan perundang-undangan, melanggar hak subjektif orang lain, bertentangan dengan kewajiban hukumnya, yang tentu saja menimbulkan kerugian bagi pihak pengembang sendiri dan pihak pembeli/konsumen.

3) Adanya Kesalahan

Untuk kesalahan dalam kasus Apartemen 45 Antasari ini ada pada perbuatan pengembang, yang melakukan pembangunan, pemasaran dan penjualan apartemen, tidak memenuhi persyaratan yang diatur dalam Undang-Undang Nomor 20 Tahun 2011 tentang Rumah Susun, yakni:

12) Shidarta, Mengungkap Kembali Konsep dasar "Perbuatan Melawan Hukum”, (Januari 2015), ～https://business-law.binus.ac.id/2015/01/27/mengungkit-kembali-konsep-dasar-perbuatanmelawan-hukum/ 
Volume 2 Nomor 2, Desember 2019

E-ISSN : 2655-7347

a. Pasal 28 huruf b UU Nomor 20 Tahun 2011 tentang Rumah Susun yang mengatur mengenai persyaratan administrasif yang harus dipenuhi pihak pengembang dimana salah satunya adalah Izin Mendirikan Bangunan.

b. Pasal 42 Ayat 2 UU Nomor 20 Tahun 2011 tentang Rumah susun, khususnya mengenai persyaratan perizinan pembangunan rumah susun, yang menurut penjelasan Pasal 42 Ayat 2 ditunjukkan dengan Izin Mendirikan Bangunan.

c. Karena pemasarannya dilakukan secara Pre Project Selling atau sebelum pembangunan selesai dilaksanakan maka perjanjian para pihak dituangkan dalam bentuk PPJB yang diatur dalam Pasal 43 Ayat 3 UU No 20 Tahun 2011 tentang Rumah Susun dan salah satu persyaratannya adalah mengenai kepemilikan IMB.

4) Adanya kerugian

Kerugian yang terjadi dalam kasus apartemen 45 Antasari ini adalah ketika pihak pembeli telah melakukan pembayaran booking fee dan cicilan DP karena pihak pengembang dalam memberikan penawaran dan/atau janji bahwa pembangunan apartemen 45 Antasari telah meyakinkan pembeli yakni dengan mengatakan bahwa telah memiliki dokumen-dokumen yang lengkap, baik kepemilikan atas lahan maupun perizinan-perizinan lainnya untuk melaksanakan pembangunan apartemen 45 Antasari yang pada kenyataan nya pembangunan apartemen 45 Antasari tersebut terhenti tanpa adanya alasan yang jelas serta diketahui bahwa pengembang belum memiliki Izin Mendirikan Bangunan dalam melakukan pemasaran dan penjualan satuan unit apartemen tersebut.

5) Adanya Hubungan Kausalitas antara perbuatan dengan kerugian

Hal tersebut ditunjukkan dengan adanya suatu hubungan sebab dan akibat antara perbuatan yang dilakukan dengan akibat yang ditimbulkan. Dengan begitu maka berdasarkan hubungan kausal tersebut dapat membebankan suatu pertanggungjawaban kepada pelaku. 
Volume 2 Nomor 2, Desember 2019

E-ISSN : 2655-7347

Berdasarkan uraian yang telah dijelaskan diatas, dapatlah diketahui bahwa pada kasus apartemen 45 Antasari perbuatan pengembang tersebut memenuhi unsur-unsur yang tercantum dalam $\mathrm{PMH}$, di mana pihak pengembang tidak memberikan informasi yang jelas terkait terhentinya pembangunan apartemen Antasari 45,selain itu pihak pengembang telah melakukan pembangunan,pemasaran dan penjualan apartemen 45 Antasari sebelum memenuhi persyaratan administrasi dan perizinan pembangunan rumah susun berupa Izin Mendirikan Bangunan. Akibat perbuatan pihak pengembang tersebut menyebabkan kerugian materill dan immaterial kepada Para Pembeli. Kerugian materill tersebut yakni berupa pembayaran booking fee dan angsuran yang telah dibayarkan untuk membeli satuan unit apartemen tersebut dan kerugian immaterial tersebut ditandai dengan telah terbuangnya waktu secara percuma, biaya maupun pemikiran serta perasaan yang tidak enak untuk pengurusan masalah tersebut, terutama lagi Para Pembeli/konsumen tidak mungkin menikmati dan memanfaatkan Unit-Unit Apartemen 45 Antasari pada Bulan Oktober 2017 sebagaimana yang dijanjikan oleh pihak pengembang.

Menyinggung sedikit apabila penulis melihat pada putusan nomor 92/Pdt.G/2017/PN.JKT.SEL bahwa pokok permasalahan dalam apartemen 45 Antasari bukan hanya mengenai ketiadaan IMB tetapi juga mengenai serah terima apartemen yang tidak sesuai dengan apa yang telah diperjanjikan dalam bentuk kontrak antara pihak pengembang dengan pembeli yakni mengenai serah terima apartemen yang seharusnya dilaksanakan pada Oktober 2017 namun ternyata sampai sekarang serah terima apartemen 45 Antasari belum dilakukan, di mana para pembeli/konsumen telah melakukan pembayaran booking fee dan Cicilan DP untuk pembelian unit apartemen 45 Antasari, tentu saja untuk hal tersebut menurut penulis, pihak pengembang juga telah melakukan perbuatan ingkar janji atau biasa disebut wanprestasi, karena adanya prestasi dari pihak pengembang yang tidak dilaksanakan atau tidak sesuai dengan apa yang diperjanjikan dalam 
Volume 2 Nomor 2, Desember 2019

E-ISSN : 2655-7347

kontrak tersebut yakni mengenai serah terima apartemen yang tidak sesuai dengan apa yang diperjanjikan.

Selanjutnya terhadap penjualan apartemen 45 Antasari dengan sistem Pre Project Selling yang dilakukan oleh pihak pengembang yakni PT. Prospek Duta Sukses yang belum memiliki izin, dalam hal ini IMB, dapatlah diketahui bahwa izin merupakan suatu keharusan bagi pihak pengembang apartemen sebelum melakukan pembangunan, di mana IMB sendiri merupakan suatu perizinan yang memberikan hak kepada pengembang untuk melakukan pembangunan apartemen selain itu dengan adanya IMB juga memberikan suatu kepastian hukum dan juga perlindungan hukum kepada pihak pembeli/konsumen, karena banyak sekali pembangunan apartemen yang belum memiliki IMB dikarenakan belum dipenuhinya persyaratan-persyaratan perizinan untuk memperoleh IMB sehingga pembangunannya tersebut pun terhenti dan tidak selesai atau tidak sesuai dengan apa yang telah diperjanjikan, namun dalam prakteknya telah dilakukan penjualan terhadap satuan unit apartemen dan bahkan sudah sold out tentu saja hal tersebut menimbulkan kerugian kepada para pembeli/konsumen, maka para pembeli dapat meminta penggantian kerugian atas dasar perbuatan melanggar hukum, karena tidak dipenuhinya ketentuan mengenai perizinan apartemen yang melanggar ketentuan dalam Undang-Undang Nomor 20 Tahun 2011 tentang Rumah Susun

Selain itu, terkait dengan tanggung jawab pengembang dalam hal tidak adanya IMB tentu saja terdapat sanksi,sanksi mengenai ketiadaan IMB tersebut berupa sanksi administratif sebagaimana yang diatur dalam Undang-Undang Nomor 28 Tahun 2002 tentang Bangunan Gedung dan PP Nomor 35 Tahun 2006 tentang Peraturan Pelaksanaan UU Nomor 28 Tahun 2002 tentang Bangunan Gedung. Diketahui bahwa menurut Pasal 5 Ayat (2) Undang-Undang Nomor 28 Tahun 2002 tentang Bangunan Gedung disebutkan: "Bangunan gedung fungsi hunian sebagaimana dimaksud dalam Ayat (1) meliputi bangunan untuk rumah tinggal tunggal, rumah tinggal deret, rumah susun, dan rumah tinggal sementara” di mana 
Volume 2 Nomor 2, Desember 2019

E-ISSN : 2655-7347

apartemen termasuk ke dalam klasifikasi rumah susun yang berbentuk rumah susun komersial. Di dalam Undang-Undang Nomor 28 Tahun 2002 tentang Bangunan Gedung di atur bahwa setiap bangunan gedung harus memenuhi persyaratan administratif dan persyaratan teknis sesuai dengan fungsi bangunan gedung yang akan digunakan, dimana syarat administratif bangunan gedung itu terdiri dari status hak atas tanah, status kepemilikan bangunan gedung, dan izin mendirikan bangunan dan memiliki IMB merupakan kewajiban dari pemilik bangunan gedung. ${ }^{13)}$

Pengaturan mengenai IMB diatur lebih lanjut dalam PP No. 36 Tahun 2005 tentang Peraturan Pelaksanaan UU No. 28 Tahun 2002 tentang Bangunan Gedung di dalam PP tersebut disebutkan bahwa setiap orang yang ingin mendirikan bangunan gedung wajib untuk memiliki IMB yang dilakukan dengan permohonan izin kepada Pemerintah Daerah setempat ${ }^{14)}$

IMB khususnya untuk IMB apartemen di DKI Jakarta diatur dalam Peraturan Gubernur Nomor 147 tahun 2018 tentang Pelayanan Perizinan dan Non Perizinan Penyelenggaraan Bangunan Gedung. Dalam Peraturan Gubernur tersebut diatur mengenai persyaratan permohonan IMB yaitu:

1) Kelengkapan dokumen administrasi;
a. Data Pemohon IMB;
b. Data Pemilik Bangunan Gedung;
c. Data tanah; dan
d. Dokumen dan surat terkait.

2) Kelengkapan dokumen teknis.

a. Data umum Bangunan Gedung; dan

b. Dokumen rencana teknis Bangunan Gedung.

13) Indonesia,Undang-Undang Nomor 28 Rahun 2002 tentang Bangunan Gedung (Tambahan Lembaran Negara Republik Indonesia Nomor 4227), Pasal 40 Ayat (2).

14) Indonesia, PP Nomor 36 Tahun 2005 tentang Peraturan Pelaksanaan Undang-Undang Nomor 28 Tahun 2002 tentang Bangunan Gedung (Tambahan Lembaran Negara Republik Indonesia Nomor 4209), Pasal 14 Ayat (1) dan Ayat (2). 
Volume 2 Nomor 2, Desember 2019

E-ISSN : 2655-7347

Dokumen dan surat terkait sebagaimana dimaksud paling sedikit harus memuat: ${ }^{15)}$

a. Asli KRK definitif atau fotokopi KRK definitif apabila asli KRK telah diserahkan sebagai persyaratan IMB terdahulu;

b. Fotokopi IPTB penanggung jawab perencana arsitektur, struktur/konstruksi termasuk geoteknik, mekanikal dan elektrikal Bangunan Gedung bagi yang dipersyaratkan dengan masa berlaku paling sedikit 3 (tiga) bulan sebelum dinyatakan habis;

c. Asli surat pernyataan penjamin konstruksi untuk bangunan rumah tinggal 3 (tiga) lantai;

d. Asli surat penyataan persetujuan warga sekitar, untuk Bangunan Gedung dengan kegiatan diizinkan bersyarat dan kegiatan diizinkan terbatas clan bersyarat;

e. Fotokopi izin bangunan yang telah dimiliki sebelumnya, seperti IP Pondasi, IP Sfruktur Menyeluruh clan IP Menyeluruh;

f. Fotokopi IMB lama beserta gambar lampirannya dan/atau perizinan bangunan yang telah dimiliki untuk permohonan IMB perubahan dan/atau penambahan; dan

g. Persyaratan lain sesuai dengan ketentuan peraturan perundang-undangan, antara lain: ${ }^{16)}$

- IPPR sesuai ketentuan peraturan perundang-undangan;

- Izin lingkungan (untuk bangunan skala Amdal atau UKLUPL) atau surat pernyataan pengelolaan lingkungan;

- Analisa dampak lalu lintas, untuk bangunan yang dipersyaratkan;

- Izin instalasi pengolahan air limbah, untuk bangunan yang dipersyaratkan;

- Izin dewatering, untuk bangunan yang dipersyaratkan;

\footnotetext{
${ }^{15)}$ Ibid, Pasal 25 Ayat (1).

${ }^{16)}$ Ibid, Pasal 25 Ayat (2).
} 
Volume 2 Nomor 2, Desember 2019

E-ISSN : 2655-7347

- Perjanjian pemenuhan kewajiban, jika dipersyaratkan dalam IPPR sesuai ketentuan peraturan perundangundangan;

- Rekomendasi kawasan kendali operasional penerbangan untuk Bangunan Gedung yang dipersyaratkan; dan

- Laporan kegiatan penanaman modal.

Apabila suatu bangunan gedung tidak memiliki IMB, maka dapat dikenakan sanksi administratif yang dilakukan secara bertahap, yang berupa: ${ }^{17)}$

- Peringatan tertulis,

- Pembatasan kegiatan pembangunan,

- Penghentian sementara atau tetap pada pekerjaan pelaksanaan pembangunan,

- Penghentian sementara atau tetap pada pemanfaatan bangunan gedung;

- Pembekuan izin mendirikan bangunan gedung;

- Pencabutan izin mendirikan bangunan gedung;

- Pembekuan sertifikat laik fungsi bangunan gedung;

- Pencabutan sertifikat laik fungsi bangunan gedung; atau

- $\quad$ Perintah pembongkaran bangunan gedung.

Pengembang juga dapat dikenakan sanksi berupa denda paling banyak 10\% dari nilai bangunan yang sedang atau telah dibangun. Jenis pengenaan sanksi ditentukan oleh berat ringannya pelanggaran yang dilakukan. ${ }^{18)}$ Dalam Pasal 115 Ayat (1) PP Nomor 36 Tahun 2005 tentang Peraturan Pelaksanaan UU Nomor 28 Tahun 2002 tentang Bangunan Gedung menyebutkan bahwa pemilik bangunan gedung yang melaksanakan pembangunan bangunan gedungnya yang melanggar ketentuan Pasal 14 Ayat (1) yakni tidak memiliki Izin Mendirikan Bangunan dikenakan sanksi penghentian sementara sampai dengan diperolehnya Izin Mendirikan Bangunan

\footnotetext{
${ }^{17)}$ Indonesia, Undang-Undang Nomor 28 Rahun 2002 tentang Bangunan Gedung (Tambahan Lembaran Negara Republik Indonesia Nomor 4227), Pasal 45 Ayat (1).

${ }^{18)}$ Ibid, Pasal 45 Ayat (2) dan Ayat (3).
} 
Volume 2 Nomor 2, Desember 2019

E-ISSN : 2655-7347

Gedung. Selain itu pengembang juga dapat dikenakan sanksi administratif berdasarkan Peraturan Daerah Nomor 1 Tahun 2015 tentang Retribusi Daerah sanksi tersebut berupa denda apabila pihak pengembang melaksanakan kegiatan konstruksi (pembangunan fisik) sebelum memiliki atau mendahului IMB, yang besarnya ditentukan berdasarkan perkalian bobot pekerjaan (Bbt) dengan proporsi pelaksanaan (V), Indeks Integrasi (It), Retribusi pembinaan penyelenggaraan bangunan gedung $(\mathrm{RPP})$ atau dengan minus. Denda = Bbt x V x lt x RPP. Besarnya bobot pekerjaan, sebagaimana dimaksud apabila untuk bangunan hunian rumah tinggal, ditetapkan sebagai berikut:

\begin{tabular}{|l|c|}
\hline \multicolumn{1}{|c|}{ Tahapan Pembangunan } & Bobot Pekerjaan \\
\hline Pekerjaan Pondasi & $5 \%$ \\
\hline Pekerjaan Struktur s/d Atap & $20 \%$ \\
\hline Pekerjaan Finishing & $25 \%$ \\
\hline Bangunan digunakan & $50 \%$ \\
\hline
\end{tabular}

Terkait hal-hal yang menyebabkan pengembang dapat melakukan penjualan satuan unit apartemen sebelum adanya IMB disebabkan oleh beberapa faktor namun hal tersebut seharusnya tidak boleh dilakukan, Pengembang dalam melakukan pembangunan rumah susun/apartemen harus memiliki beberapa izin terlebih dahulu seperti izin lokasi, izin proyek, Surat Izin Penunjukkan Penggunaan Tanah (SIPPT), Surat Persetujuan Prinsip Pembebasan Lokasi (SP3L) serta IMB. IMB baru bisa diperoleh oleh pengembang setelah segala perizinan seperti izin lokasi, izin proyek, 
Volume 2 Nomor 2, Desember 2019

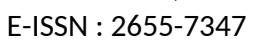

Surat Izin Penunjukkan Penggunaan Tanah (SIPPT), Izin Lingkungan, IPPR tersebut dilengkapi dan IMB itu akan ada ketika pihak pengembang ingin membangun fisik bangunan gedung, karena pada prakteknya, banyak pengembang yang hanya memiliki perizinan seperti izin lokasi saja sedangkan izin proyek, SIPPT, izin lokasi, dan izin lainnya yang belum diperoleh pengembang dan tetap melakukan pembangunan.

Terkait dengan perizinan apartemen, dalam prakteknya ada yang dinamakan Izin Pendahuluan (IP), di mana Izin Pendahuluan (IP) ini merupakan izin sebelum diterbitkannya IMB, karena pemberian IMB dilakukan bertahap di mana pengaturan mengenai mekanisme jangka waktu pemberian IMB setiap daerah itu berbeda tergantung pada peraturan daerah masing-masing. Sedangkan pihak pengembang memikirkan bahwa waktu adalah uang apabila ia menunggu lama untuk didapatkannya IMB maka pembangunannya pun akan semakin lama terlaksana, yang juga menghambat pengembang untuk melakukan pemasaran dan penjualan apartemen. Oleh karena itu pihak pengembang dapat meminta izin pendahuluan (IP) untuk membangun yang dimungkinkan oleh Peraturan Gubernur Nomor 129 Tahun 2012 tentang Tata Cara Pemberian Pelayanan Di Bidang Perizinan Bangunan, misalnya pertama Izin Pendahuluan (IP) tentang Pondasi jadi pihak pengembang hanya boleh membangun pondasi saja, kemudian Izin Pendahuluan (IP) tentang struktur bangunannya, di mana pihak pengembang hanya boleh membangun struktur bangunan saja kemudian setelah semua terbangun menjadi suatu bangunan gedung bisa saja Izin Mendirikan Bangunan tersebut baru diperoleh.

Namun Peraturan Gubernur Nomor 129 Tahun 2012 tentang Tata Cara Pemberian Pelayanan Di Bidang Perizinan Bangunan telah diganti dengan berlakunya Peraturan Gubernur Nomor 147 Tahun 2018 tentang Pelayanan Perizinan dan Non Perizinan Penyelenggaraan Bangunan. Di mana IP sudah diganti dengan sebutan IMB Pondasi yakni izin yang diberikan untuk melakukan kegiatan membangun sesuai 
Volume 2 Nomor 2, Desember 2019

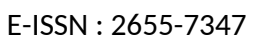

tahapan kegiatan pelaksanaan pembangunan sewaktu menunggu terbitnya Izin Mendirikan Bangunan (IMB) definitif.

Dalam Peraturan Gubernur Nomor 147 Tahun 2018 tentang Pelayanan Perizinan dan Non Perizinan Penyelenggaraan Bangunan Gedung tidak dikenal namanya Izin Pendahuluan (IP) namun diatur mengenai penerbitan IMB secara bertahap yang mana IMB secara bertahap itu dinamakan IMB Pondasi, dengan diberikannya IMB Pondasi maka pengembang dapat melaksanakan kegiatan berupa penggalian tanah, dinding penahan tanah, pelaksanaan uji beban, dewatering, pemasangan pondasi tiang pancang/bor dan/atau pemasangan pondasi tower crane.

Bahwa dengan diberikannya IP atau IMB Pondasi tersebut seringkali pihak pengembang merasa sudah memiliki izin untuk dapat melakukan pembangunan dan penjualan apartemen, karena IP atau IMB Pondasi sendiri merupakan suatu perizinan yang dapat dimohonkan oleh pemohon apabila IMB belum diterbitkan. Salah satu alasan mengapa IMB nya belum diterbitkan adalah karena adanya persyaratan perizinan untuk memperoleh IMB yang belum dipenuhi, misalnya untuk memperoleh IMB apartemen makan pihak pengembang harus memenuhi persyaratan perizinan seperti:

- IPPR sesuai ketentuan peraturan perundang-undangan;

- Izin Prinsip

- IPPT (Izin Peruntukkan Penggunaan Tanah)

- Izin lingkungan (untuk bangunan skala Amdal atau UKLUPL) atau surat pernyataan pengelolaan lingkungan;

- Analisa dampak lalu lintas, untuk bangunan yang dipersyaratkan;

- Izin instalasi pengolahan air limbah, untuk bangunan yang dipersyaratkan;

- Izin dewatering, untuk bangunan yang dipersyaratkan;

- Perjanjian pemenuhan kewajiban, jika dipersyaratkan dalam IPPR sesuai ketentuan peraturan perundangundangan; 
Volume 2 Nomor 2, Desember 2019

E-ISSN : 2655-7347

- Rekomendasi kawasan kendali operasional penerbangan untuk Bangunan Gedung yang dipersyaratkan; dan

- Laporan kegiatan penanaman modal.

Jika salah satu syarat tersebut belum dipenuhi dan pihak pengembang pun tidak melakukan permohonan IMB maka IMB tersebut tidak akan diterbitkan. Untuk apartemen yang berhak untuk mengeluarkan IMB adalah DPM PTSP Provinsi DKI Jakarta.DPM PTSP Provinsi DKI Jakarta bersifat pasif, yang mana ia akan menerbitkan IMB apabila adanya permohonan dari pemohon dan apabila segala persyaratan untuk memperoleh IMB tersebut telah dipenuhi. Hal ini lah yang menjadi alasan pengembang melakukan penjualan apartemen sebelum adanya IMB dikarenkan cukup banyak persyaratan yang harus dipenuhi oleh pihak pengembang yang melibatkan instansi-instansi yang berbeda dalam pemenuhan persyaratan tersebut, yang tentunya akan memakan waktu pengembang untuk dapat melakukan penjualan apartemen, sedangkan pihak pengembang memerlukan uang dari para pembeli yang akan digunakan untuk melakukan pembangunan apartemen.

Menyinggung kembali terkait apabila pengembang melakukan penjualan apartemen sebelum adanya IMB berdasarkan data wawancara yang telah penulis peroleh, bahwa hal tersebut tidaklah dapat dibenarkan dengan memiliki IP atau IMB Pondasi pengembang dapat melakukan pembangunan dan penjualan apartemen karena hal tersebut bertentangan dengan Undang-Undang Nomor 20 Tahun 2011 tentang Rumah Susun di mana dalam Undang-Undang Nomor 20 Tahun 2011 tentang Rumah Susun sendiri khususnya dalam Pasal 28 dan Pasal 42 Ayat 2 diatur bahwa dalam melakukan pembangunan dan penjualan apartemen pihak pengembang harus memiliki Izin Mendirikan Bangunan terlebih dahulu untuk menjamin kepastian hukum bangunan gedung dan juga untuk melindungi konsumen dengan adanya perizinan yang lengkap dan jelas sesuai dengan peraturan perundang-undangan khususnya Undang-Undang Nomor 20 Tahun 2011 tentang Rumah Susun. 
Volume 2 Nomor 2, Desember 2019

E-ISSN : 2655-7347

Di mana apartemen harus tunduk terhadap Undang-Undang tersebut karena apartemen sendiri merupakan klasifikasi dari rumah susun dalam bentuk rumah susun komersial. Selain itu tidak adanya sanksi yang tegas dalam Undang-Undang Nomor 20 Tahun 2011 tentang Rumah Susun apabila pengembang belum memiliki Izin Mendirikan Bangunan juga merupakan alasan yang mengakibatkan dalam prakteknya banyak pihak pengembang tetap melakukan pembangunan dan penjualan apartemen sebelum diterbitkannya IMB.

IMB sendiri merupakan wujud izin yang diharuskan oleh pemerintah untuk melakukan pembangunan agar sesuai dengan peruntukkannya, rencana tata ruang dan kota, serta untuk menjamin kepastian hukum dalam penyelenggaraan bangunan gedung, bahwa dengan adanya IMB sendiri dapat dipastikan bangunan tersebut memiliki keandalan teknis bangunan yang menjamin keamanan dan kenyamanan karena telah memperoleh perizinan-perizinan lain yang merupakan syarat untuk memperoleh IMB yang tidak kalah pentingnya dalam melakukan pembangunan bangunan gedung sebelum diberikannya IMB.

\section{Penutup}

\section{A. Kesimpulan}

Berdasarkan uraian pembahasan di atas maka kesimpulan yang dapat diambil adalah dasar dari suatu pembebanan tanggung jawab terhadap pihak pengembang terkait ketiadaan Izin Mendirikan Bangunan adalah Tanggung jawab berdasarkan unsur kesalahan yang erat kaitannya dengan Perbuatan Melawan Hukum sebagaimana diatur dalam Pasal 1365 KUHPerdata, di mana menurut Pasal 1365 KUHPerdata mewajibkan seseorang untuk mengganti kerugian atas perbuatan yang telah dilakukannya yang menyebabkan kerugian bagi orang lain yakni berupa pemberian ganti rugi materill sesuai dengan apa yang telah dibayarkan oleh pembeli kepada pengembang dapat juga mencakup kerugian immaterill berdasarkan nilai yang wajar dan adil. Selain itu terkait dengan ketiadaan Izin Mendirikan Bangunan dalam 
Volume 2 Nomor 2, Desember 2019

E-ISSN : 2655-7347

penjualan apartemen Antasari 45, pihak pengembang dapat dikenakan sanksi administratif sebagaimana yang diatur dalam Undang-Undang Nomor 28 Tahun 2002 tentang Bangunan Gedung dan PP Nomor 36 Tahun 2005 tentang Peraturan Pelaksanaan UU Nomor 28 Tahun 2002 tentang Bangunan Gedung dimana sanksi administratif tersebut dapat berupa denda sebesar 10\% dari total nilai bangunan yang telah dibangun, serta penghentian sementara sampai dengan diperolehnya Izin Mendirikan Bangunan dan dapat dikenakan sanksi administratif yang berupa denda sebagaimana diatur dalam Perda Nomor 1 Tahun 2015 tentang Retribusi Daerah sesuai dengan perkalian bobot pekerjaan yang dilakukan.

Dalam prakteknya banyak pengembang yang melakukan pemasaran dan penjualan apartemen sebelum memiliki Izin Mendirikan Bangunan, hal tersebut dapat terjadi dikarenakan tidak adanya pengawasan dalam melakukan penjulan apartemen tersebut, tidak adanya sanksi yang tegas dalam Undang-Undang Nomor 20 Tahun 2011 tentang Rumah Susun dan mekanisme untuk memperoleh Izin Mendirikan Bangunan yang cukup panjang dan memakan waktu yang cukup lama juga merupakan hal yang menyebabkan banyak pengembang melakukan pemasaran dan penjualan apartemen sebelum adanya Izin Mendirikan Bangunan karena dianggap menghambat pengembang dalam melakukan penjualan apartemen, selain itu untuk mendapatkan suatu Izin Mendirikan Bangunan harus dilakukan dengan mekanisme

permohonan yang dilakukan pihak pengembang kepada suku dinas terkait sesuai dengan luasan lahan yang akan dibangun.

\section{B. Saran}

Berdasarkan hasil penelitian yang dilakukan mengenai tanggung jawab pengembang dalam penjualan satuan unit apartemen terkait ketiadaan Izin Mendirikan Bangunan, maka saran yang dapat disampaikan kepada pemerintah DKI Jakarta yaitu untuk dapat melakukan pengawasan dengan cara membuat pendataan seluruh bangunan gedung di wilayah DKI Jakarta guna mengetahui jumlah bangunan gedung yang tidak memiliki Izin Mendirikan Bangunan. Bagi bangunan gedung 


\section{Jurnal Huknm Adigamâ}

Volume 2 Nomor 2, Desember 2019

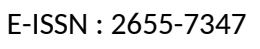

khususnya rumah susun dalam bentuk apartemen yang tidak memiliki Izin Mendirikan Bangunan dapat diberikan sanksi yang tegas khususnya sanksi tersebut diatur dalam Undang-Undang Nomor 20 Tahun 2011 tentang Rumah Susun agar adanya pembatasan perbuatan yang dilakukan oleh pengembang dalam melakukan pembangunan, pemasaran dan penjualan apartemen serta memberikan efek jera kepada pihak pengembang. Adanya efek jera tersebut diharapkan pengembang dapat dengan segera melengkapi kewajibannya yang telah diatur dalam undang-undang, selain itu mempermudah alur tahapan ataupun mekanisme untuk mendapatkan Izin Mendirikan Bangunan.

\section{Daftar Pustaka}

\section{A. Buku}

Hamzah, Andi. Kamus Hukum. (Jakarta: Ghalia Indonesia, 2005).

Siwi Kristiyanti, Celina Tri. Hukum Perlindungan Konsumen. (Jakarta: Sinar Grafika, 2009).

Fuady, Munir. Perbuatan Melawan Hukum. Cetakan ke-4. (Bandung: PT Citra Aditya Bakti).

Khairandy, Ridwan. Hukum Kontrak Indonesia dalam Perspektif Perbandingan (Bagian Pertama). (Yogyakarta: FH UII Press, 2013).

Sogar Simamora, Yohanes. Penerapan Prinsip Caveat Vendor Sebagai Sarana Perlindungan Bagi Konsumen Perumahan Di Indonesia. (Surabaya: Universitas Airlangga,1996).

\section{B. Jurnal}

S. Aminah, Amarendradan R. Suharto. “Tinjauan Yuridis Terhadap Pembangunan Apartemen Utara Yogyakarta Ditinjau Dari Undang-Undang Nomor 32 Tahun 2009 Tentang Perlindungan Dan Pengelolaan Lingkungan Hidup”. Diponegoro Law Review.Volume 5 Nomor 2 Tahun 2016.

Ridwan, M. “Analisis Yuridis Kekuatan Hukum Atas Sertipikat Satuan Rumah Susun Hunian Atau Campuran Pasca Terbitnya Undang-Undang Nomor 20 tahun 2011 tentang Rumah Susun”. Premise Law Jural. Volume 8 Tahun 2017.

Yudhantaka, Lintang. "Keabsahan Kontrak Jual Beli Rumah Susun dengan Sistem Pre Project Selling”. Jurnal Yuridika.Volume 32 No.1 Januari 2017. 
Volume 2 Nomor 2, Desember 2019

E-ISSN : 2655-7347

\section{Peraturan}

Indonesia. Undang-Undang Nomor 20 Tahun 2011 tentang Rumah Susun.

Indonesia. Undang-Undang Nomor 28 Tahun 2002 tentang Bangunan Gedung.

Indonesia. Peraturan Pemerintah Nomor 36 Tahun 2005 tentang Peraturan Pelaksanaan Undang-Undang Nomor 28 Tahun 2002 tentang Bangunan Gedung.

Indonesia. Peraturan Gubernur Nomor 147 Tahun 2018 tentang Pelayanan Perizinan dan Non Perizinan Penyelenggaraan Bangunan Gedung.

Indonesia. Peraturan Menteri Pekerjaan Umum dan Perumahan Rakyat Nomor 05/PRT/M/2016 tentang Izin Mendirikan Bangunan Gedung.

\section{Internet}

Shidarta. Mengungkap Kembali Konsep dasar "Perbuatan Melawan Hukum”.

https://business-law.binus.ac.id/2015/01/27/mengungkitkembali-konsep-dasar-perbuatan melawan-hukum/ 